\title{
Intersection of Landscape, Anthropocene and Fourth Paradigm
}

\author{
Aliyu Salisu Barau \\ Faculty of Built Environment \\ Universiti Teknologi Malaysia \\ 81310, Johor, Malaysia \\ email: aliyubarau1@yahoo.co.uk \\ A.N.M. Ludin \\ Centre for Innovative Planning and Development \\ Universiti Teknologi Malaysia \\ 81310, Johor, Malaysia \\ email: b-anazri@utm.my
}

Accepted: 18 June 2012

Published: 11 July 2012

\begin{abstract}
This review explores landscape science in the proposed age of the Anthropocene and Fourth Paradigm. Both the Anthropocene and the Fourth Paradigm put landscape science to task, due to the severity of landscape challenges. The article aims to link the concepts of the Anthropocene, the Fourth Paradigm and landscape sustainability in the 21st century. Different sources of publications and information were used to analyse, synthesise and explain the state of landscape research. We searched Thomson Reuters Web of Knowledge, Scopus, and Google Scholar for contents on this article's key themes - globalisation, urbanisation, the Anthropocene and the Fourth Paradigm. We argue that globalisation and urbanisation are the key driving forces behind landscape change. These driving forces represent the scales of human impact on landscapes. Landscape science plays a major role in the age of data revolution and unprecedented landscape change. The review suggests that landscape scientists and landscape societies should chart a new course for landscape research to exploit the benefits of data to advance landscape sustainability.
\end{abstract}

Keywords: anthropocene, fourth paradigm, landscape, globalisation, urbanisation

This review is licensed under a Creative Commons Attribution-Non-Commercial-NoDerivs 3.0 Germany License. http://creativecommons.org/licenses/by-nc-nd/3.0/de/ 


\section{Imprint / Terms of Use}

Living Reviews in Landscape Research is a peer reviewed open access journal published by the Leibniz Centre for Agricultural Landscape Research (ZALF), Eberswalder Straße 84, 15374 Müncheberg, Germany. ISSN 1863-7329.

This review is licensed under a Creative Commons Attribution-Non-Commercial-NoDerivs 3.0 Germany License: http://creativecommons.org/licenses/by-nc-nd/3.0/de/. Figures that have been previously published elsewhere may not be reproduced without consent of the original copyright holders.

Because a Living Reviews article can evolve over time, we recommend to cite the article as follows:

Aliyu Salisu Barau and A.N.M. Ludin,

"Intersection of Landscape, Anthropocene and Fourth Paradigm",

Living Rev. Landscape Res., 6, (2012), 1. URL (accessed < date>):

http://www.livingreviews.org/lrlr-2012-1

The date given as $<$ date $>$ then uniquely identifies the version of the article you are referring to.

\section{Article Revisions}

Living Reviews supports two ways of keeping its articles up-to-date:

Fast-track revision A fast-track revision provides the author with the opportunity to add short notices of current research results, trends and developments, or important publications to the article. A fast-track revision is refereed by the responsible subject editor. If an article has undergone a fast-track revision, a summary of changes will be listed here.

Major update A major update will include substantial changes and additions and is subject to full external refereeing. It is published with a new publication number.

For detailed documentation of an article's evolution, please refer to the history document of the article's online version at http://www.livingreviews.org/lrlr-2012-1. 


\section{Contents}

1 Introduction $\quad 5$

2 Defining the Anthropocene $\quad 6$

3 Urbanisation and globalisation as the drivers of Anthropocene 12

4 State of the research: Landscape and the Anthropocene 13

5 Fourth Paradigm and landscape research $r$

6 Discussion $\quad 20$

7 Conclusions 21

8 Acknowledgements $\quad 21$

$\begin{array}{lr}\text { References } & 22\end{array}$

\section{List of Tables}

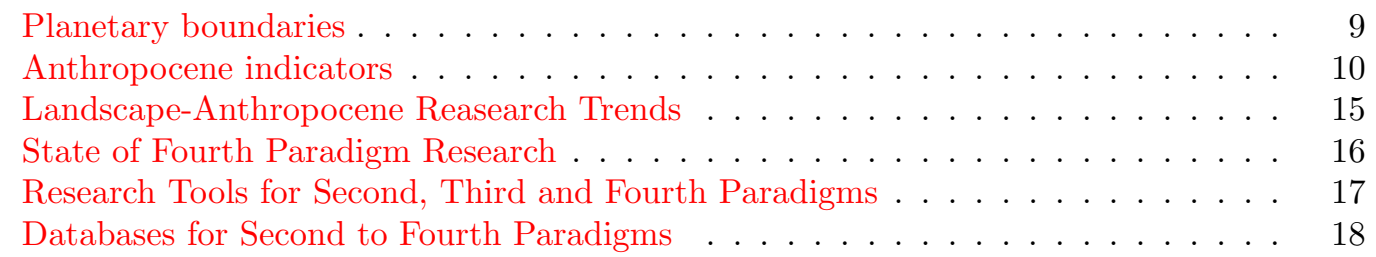





\section{Introduction}

Landscape data is crucial to the effectiveness of science and policy on sustainability. Mass data production and anthropogenic pressure on landscapes present a challenge and an opportunity for sustainability. On the one hand, anthropogenic pressures constitute threats to biophysical thresholds, called planetary boundaries (Rockström et al., 2009a). The nine boundaries include climate change, ocean acidification, stratospheric ozone depletion, disruption of the nitrogen and phosphorus cycles, global freshwater use, land use changes, biodiversity loss, aerosol loading in the atmosphere and chemical pollution. Crossing most of the planetary boundaries could be a direct consequence of the overuse of landscapes. Many scientists hypothesise that enormous pressure on landscapes is pushing Earth into the Anthropocene - a new geological age (Lövbrand et al., 2009; Zalasiewicz et al., 2011). On the other hand, planet Earth is witnessing the explosion of various forms of data. In the year 2010 alone, 1,200 exabytes (or billion gigabytes) worth of data were created (The Economist, 2010). The Research Data Strategy Working Group (2011) suggests that all types of digital information could be considered research data, provided that researchers use them as a primary source. Types of data include: 1) raw data, which is an unprocessed observation of an event; 2) processed data, which is calibrated or corrected raw data; 3) derived data, which is extracted from raw data based on a particular need; 4) textual data, which emanates from research projects' textual data - bibliographies, texts, surveys, etc. The Fourth Paradigm or Data Intensive science entails using scientific data, also referred to as "big data" or "data deluge", for the analysis, visualisation, exploration, communication and dissemination of research output (Hey, 2011). This paradigm is potentially beneficial for landscape sustainability. The post-industrial information age facilitates the understanding of complex socio-ecological crises (Naveh, 2007).

Landscape science as a meta-discipline is an overarching subject comprising many disciplines that explain the biophysical and socio-cultural nature of the Earth (Antrop, 2000a,b). As such, it passes through several paradigm shifts. Recently, global science and the policy community has identified with the paradigm of planetary boundaries. This paradigm incorporates arguments put forward by advocates of the Anthropocene epoch. However, there is a need to explore the most critical driving forces, and how they affect landscapes. One of the strengths of landscape research is its openness to interdisciplinarity (Tress et al., 2006; Cosgrove, 2004). Only disciplines with a strong inclination for interdisciplinarity can play a significant role in resolving the massive human impact on the planet. On that premise, it is worth exploring the connection between landscapes, big data and the Anthropocene. Landscape researchers develop or borrow techniques to analyse various landscape issues (Uuemaa et al., 2009). Despite this established culture, the challenges that landscape research addresses keep changing dimensions. It is normal for sciences to shift grounds during crises (Kuhn, 1970), the real crisis at present being the massive pressure placed on planet Earth.

This article aims to link the concepts of the Anthropocene, Fourth Paradigm and landscape sustainability in the 21st century. The specific objectives are:

- To position landscape sustainability in the context of the Anthropocene and Fourth Paradigm

- To identify the bolder driving forces for landscape change within the Anthropocene debate

- To highlight the role of landscape science in addressing the dynamics of global landscape and sustainability crises

Academic publications, conferences, seminars and research groups offer many perspectives on the landscape sustainability and the Anthropocene debate. It is important to explain the state of landscape research in the context of the Anthropocene and the Fourth Paradigm. We took a retrospective and prospective look at the dimensions of the research themes from a multidisciplinary perspective. This review focused on three keywords - the Anthropocene, the Fourth Paradigm and 
Landscape. We searched for these keywords in peer-reviewed publications archived in Thomson Reuters Web of Knowledge, Elsevier's Scopus and Google Scholar. Other auxiliary sources of information from other academic websites were also used. Relevant textbooks were also included as reading material for this review.

This review comprises seven sections, starting with an introduction that outlines the research background. It includes the aim and objectives, the research need and its conceptual and theoretical underpinnings. The introductory Section 1 also highlights the review methods. Section 2 discusses the Anthropocene and its link with landscape. Section 3 explains why urbanisation and globalisation should be key players in the ongoing debates on Anthropocene. The Sections 4 and 5 provide insights into the state of research on landscape, Anthropocene and the Fourth Paradigm. Section 6 presents the arguments of this paper and its limitations, as well as areas for further study. Section 7 summarises further action for landscape scientists and researchers. Figure 1 shows the connections to subjects explored in this review.

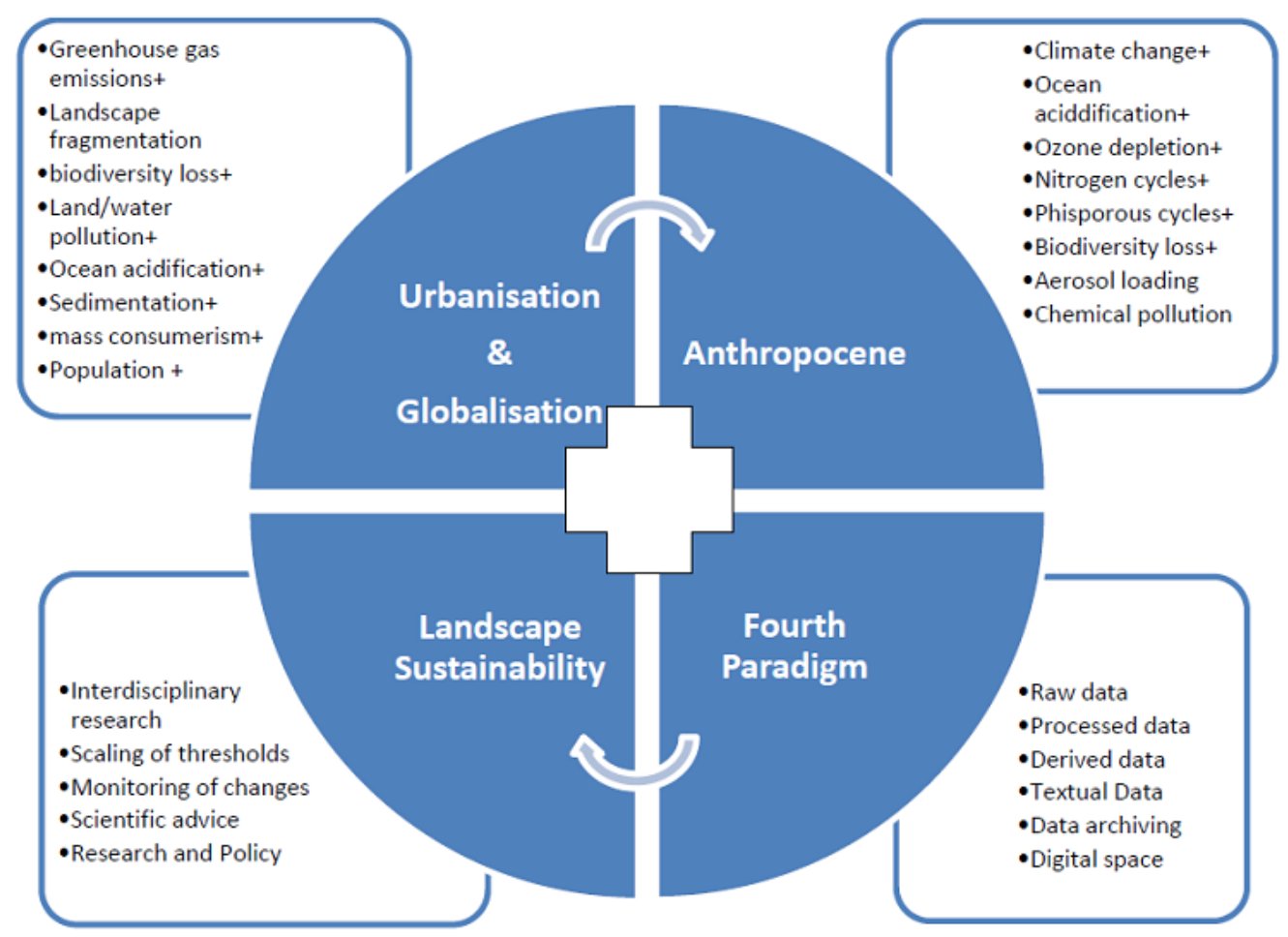

Figure 1: A conceptual framework of the interrelationship between the research key themes.

\section{Defining the Anthropocene}

Paul Crutzen, the Nobel laureate, and Eugene Stoermer coined the term Anthropocene in 2000 for a brand new human dominated geologic age (Lövbrand et al., 2009; Slaughter, 2010). The term Anthropocene is derived from two Greek words, anthro (human) and cene (new). The term signifies the gradual exit of the planet Earth from its current geological epoch, the Holocene (Steffen et al., 2011). However, the term remains as "proposed" as it is "increasingly employed" to define the transition to the complete anthropogenisation of planet Earth (Zalasiewicz et al., 2008). 
Accelerated human impacts prompted this new scientific postulation. The term has not yet been formalised by the stratigraphic community. However, several efforts have responded to this concern (Robin and Steffen, 2007; Zalasiewicz et al., 2010). For instance, the International Commission on Stratigraphy (ICS) discussed the Anthropocene as a potential geological era in its 2012 meeting (Sachs, 2011). Similarly, the ICS Subcommission on Quaternary Stratigraphy established an Anthropocene Working Group. The Anthropocene has also been the subject of various academic conferences around the world. The proponents of the Anthropocene have stratigraphic ideas in mind when they coined the term. However, landscape scientists have a major stake in this debate. Humans are not creating or laying a new geologic strata; rather, landscapes are being transformed, in most cases, negatively. It is not surprising that Crutzen (2002) attributes the Anthropocene to the industrial revolution.

Some researchers consider the Anthropocene on the scale of millennia. Ruddiman (2003) suggests that the Anthropocene commenced some 8,000 years ago. Others trace it to the past 6,000 years (Schlütz and Lehmkuhl, 2009) or even to the last fifty years, when natural drainage systems came under massive human pressure (Meybeck, 2003). It is apparent that consensus is lacking on the timing of the Anthropocene and its impact across geographic areas. Apparently, further dialogue is required between the scientists concerned. The term is overshadowed by unpredictability, misunderstandings and how humans dominate the pre-existing natural systems (Ellis and Haff, 2009). Naturally, landscape scientists have the potential to corroborate uncertainties associated with the concept of the Anthropocene. An editorial published by Nature (2011) sheds light on the complexities of the Anthropocene:

$[\mathrm{T}]$ he driving force behind the geological transition it labels is not a continental rearrangement, massive volcanism or an extraterrestrial impact - forces that have reshaped the planet in the past. Yet the Anthropocene does deserve proper recognition. It reflects a grim reality on the ground, and it provides a powerful framework for considering global change and how to manage it.

Defining the Anthropocene is meaningless without reference to the Holocene. The Holocene is still the ratified geological epoch of planet Earth in the 21st century. The Holocene (which means "early recently") is a Quaternary system epoch whose stratigraphy is marked by climate change, geophysical processes, sea-level rises, vegetation development, faunal migrations, human evolution and activity (Walker et al., 2009). This epoch has created a stable condition for human survival, and the development and use of landscape resources. The overkill theory which associates the mass decimation of animal species to humans at the beginning of the Holocene has been disproved in recent studies (Grayson, 2008). This argument aims to show that human-induced biodiversity loss is not a feature of the early Holocene.

The science of geology has been debating geological age ratification and terminologies for a long time. Walker et al. (2009) point out that, since the late 19th century, scientists have debated the nomenclature and timing of the Holocene. Arguments were advanced on the need to identify the boundary of the Holocene and the Pleistocene based on climatic and geological variables. Therefore, the ongoing debate on the Anthropocene is common to geological age benchmarking. The most important aspect is to track human impact. Overstepping the planetary boundaries constitutes a source of pressure for planet Earth (Rockström et al., 2009a; Galaz et al., 2012). The literature contains abundance reference to human excesses within the nine boundaries. Rockström et al. (2009b) observe that environmental changes in the Holocene do not disrupt the conditions that are ideal for the survival of humans. Temperature, freshwater availability and biogeochemical cycles were within a relatively narrow range during the Holocene. The boundary between the Holocene and the Anthropocene could be determined by the extent and rate at which humans modified planet Earth. Compared to the pre-industrial state of the planet, the current environmental change levels exceed the levels known since the time the Holocene was ratified. According to Syvitski (2012), the 
unique traits of geologic epochs are defined by "what happens" between one epoch and another. It could be a shift in climate regime, mass extinction or bulk change in the composition of sedimentary rocks. The rates of modification of the planet between pre-industrial and post-industrial eras are given in Table 1. If we consider climate change and biodiversity boundaries as examples, then the anthropogenic pressure arguments advanced by proponents of the Anthropocene are correct.

It is important to add that the values given in Table 1 merely portray the world average. These values are most probably higher for certain geographical levels, such as cities. Table 2 shows a number of indicators and drivers that many researchers associate with the proposed Anthropocene. For the indicators shown in Tables 1 and 2, big data is required to explore the levels of impacts on different landscape systems.

\section{Connections between landscape and the Anthropocene}

Landscapes evolve over time from the overlap of various geologic stratifications of different epochs (Figure 2). Changes in climate and geologic formations create the necessary conditions that accommodate life on landscapes (Meadows, 2001). Landscape scientists and researchers consistently explain landscapes in the light of myriad theories. The response of landscape scientists to the Anthropocene debate would be unsatisfactory without reference to various landscape theories.

\begin{tabular}{|c|c|c|c|c|c|}
\hline $\begin{array}{l}\text { Eonothem } \\
\text { Eon }\end{array}$ & $\begin{array}{l}\text { Erathem } \\
\text { Era }\end{array}$ & System Period & $\begin{array}{l}\text { Series } \\
\text { Epoch }\end{array}$ & $\begin{array}{l}\text { Stage } \\
\text { Age }\end{array}$ & $\begin{array}{l}\text { Age } \\
\text { (Ma) }\end{array}$ \\
\hline \multirow{16}{*}{ Phanerozoic } & \multirow{16}{*}{ Cenozoic } & \multirow{5}{*}{ Quaternary } & Holocene & & 0.00117 \\
\hline & & & \multirow{4}{*}{ Pleistocene } & Upper & 0.126 \\
\hline & & & & Ionian & 0.78 \\
\hline & & & & Calabrian & 1.806 \\
\hline & & & & Gelasian & 2.588 \\
\hline & & \multirow{8}{*}{ Neogene } & \multirow{2}{*}{ Pliocene } & Piacenzian & 3.600 \\
\hline & & & & Zanclean & 5.332 \\
\hline & & & \multirow{6}{*}{ Meiocene } & Messinian & 7.246 \\
\hline & & & & Tortonian & 11.608 \\
\hline & & & & Serravalian & 13.82 \\
\hline & & & & Langhian & 15.97 \\
\hline & & & & Burdigalian & 20.43 \\
\hline & & & & Aquitanian & 23.03 \\
\hline & & \multirow{3}{*}{ Paleogene } & \multirow{2}{*}{ Oligocene } & Chattian & $28.4 \pm 0.1$ \\
\hline & & & & Rupellian & $33.9 \pm 0.1$ \\
\hline & & & Eocene & Priabonian & $37.2 \pm 0.1$ \\
\hline
\end{tabular}

Figure 2: Landscape development is not independent of systematic and time dependent geologic/climatic transformations. This figure is developed based on a section of the ICS 2010 stratigraphic chart (http: //www. stratigraphy.org/ics\%20chart/09_2010/StratChart2010.pdf).

Several theories explain landscape development from different viewpoints. To begin with, the 19th century work of John Playfair and William Morris Davies' Ideal Cycle theory remains a key reference in landscape evolution (Dutch, 1999). Davisian theorists view landscapes as phenomena that develop over a long period of time, based on the working of geophysical processes. Penck's slope/erosion theory (of 1924) and King's pediplain theory of 1953 (Hack, 1960) are closely related to Davies' Geographic Cycle theory. Both theories emphasise that landscapes develop in stages. 
Table 1: Planetary boundaries

\begin{tabular}{|c|c|c|c|c|}
\hline Planetary Boundary & Parameters & Boundary & Current Status & Pre-Industrial \\
\hline \multirow[t]{2}{*}{ Climate change } & $\begin{array}{l}\mathrm{CO}_{2} \text { parts per } \\
\text { million (ppm) }\end{array}$ & 350 & 392 & 280 \\
\hline & $\begin{array}{l}\text { Radiative forc- } \\
\text { ing: watts per } \\
\text { meter squared }\end{array}$ & 1 & 1.5 & 0 \\
\hline Ocean acidification & $\begin{array}{l}\text { Saturation state } \\
\text { of aragonite in } \\
\text { water }\end{array}$ & 2.75 & 2.90 & 3.44 \\
\hline Stratospheric ozone & Dobson units & 276 & 283 & 290 \\
\hline Nitrogen cycle & $\begin{array}{l}\text { Millions of } \\
\text { tonnes/yr re- } \\
\text { moved from at- } \\
\text { mosphere }\end{array}$ & 35 & 121 & 0 \\
\hline Phosphorus cycle & $\begin{array}{l}\text { Millions of } \\
\text { tones/yr enter- } \\
\text { ing ocean }\end{array}$ & 11 & $8.5-9.5$ & -1 \\
\hline Freshwater use & $\begin{array}{l}\mathrm{km}^{3} / \mathrm{yr} \text { human } \\
\text { consumption }\end{array}$ & 4,000 & 2,600 & 415 \\
\hline Land use change & $\begin{array}{l}\% \text { of global land } \\
\text { converted to } \\
\text { cropland }\end{array}$ & 15 & 11.7 & low \\
\hline Biodiversity loss & $\begin{array}{l}\text { Species per mil- } \\
\text { lion/yr extinct }\end{array}$ & 10 & $>100$ & $0.1-1$ \\
\hline Aerosol loading & $\begin{array}{l}\text { Particulate con- } \\
\text { centration in } \\
\text { atmosphere }\end{array}$ & $\begin{array}{c}\text { to be } \\
\text { determined }\end{array}$ & & \\
\hline Chemical pollution & $\begin{array}{l}\text { Several possibili- } \\
\text { ties }\end{array}$ & $\begin{array}{c}\text { to be } \\
\text { determined }\end{array}$ & & \\
\hline
\end{tabular}

Based on Rockström et al. (2009b) and updated according to http://blogs. ei. columbia.edu/2011/08/05/ have-we-crossed-the-9-planetary-boundaries/. Reprinted by permission from Macmillan Publishers Ltd. 
Aliyu Salisu Barau and A.N.M. Ludin

Table 2: Anthropocene indicators

\begin{tabular}{|c|c|c|}
\hline Drivers & Indicators & References \\
\hline Atmospheric pollution & $\begin{array}{l}\mathrm{CO}_{2} \text { hike to between } \\
280-387 \mathrm{ppm}\end{array}$ & Raupach and Canadell (2010) \\
\hline Land use / land cover change & $\begin{array}{l}\text { Proliferation of anthropogenic } \\
\text { biomes; } 70 \% \text { of ice free areas } \\
\text { are under stress }\end{array}$ & $\begin{array}{l}\text { Boyle et al. (2011); Ellis } \\
\text { (2011); Ellis and Ramankutty } \\
\text { (2008); Ellis et al. (2010) }\end{array}$ \\
\hline Oxygen decline & $\begin{array}{l}\text { decline of biodiversity, and } \\
\text { disruption of biogeochemical } \\
\text { and environmental feedback } \\
\text { systems }\end{array}$ & Falkowski et al. (2011) \\
\hline Population density & $\begin{array}{l}\text { disproportionate land use in- } \\
\text { tensity }\end{array}$ & Ruddiman and Ellis (2009) \\
\hline $\begin{array}{l}\text { Mining, irrigation, civil con- } \\
\text { structions }\end{array}$ & $\begin{array}{l}\text { Sedimentation, siltation, desic- } \\
\text { cation }\end{array}$ & Syvitski and Kettner (2011) \\
\hline Manufacturing & Global warming & Zalasiewicz et al. (2011) \\
\hline Urbanisation \& Transportation & Landscape fragmentation & $\begin{array}{l}\text { Meadows et al. (2005); Li et al. } \\
\text { (2009); Tian et al. (2011) }\end{array}$ \\
\hline
\end{tabular}

These theories fit into the characteristics of the Holocene/Quaternary period. On the other hand, Catastrophism theory is an alternative to the Davisian theory. Catastrophists argue that landscapes originate from sudden short-lived and violent processes (Turney and Brown, 2007; Austin, 2009). Such abrupt and fast changes cause large-scale permutations of landscapes. Still on the development of landscapes, Creationists' theory suggests that violent natural forces eliminate organic life, setting scenes for a new landscape development phase. The latter two theories bear semblances with the underlining feature of the Anthropocene, which essentially highlights the disruption of landscapes.

Landscape attracted the interest of several disciplines long before interdisciplinarity became popular. According to Zube et al. (1982), human-landscape interaction gives rise to four paradigms:

- Expert paradigm (landscape evaluation)

- Psychophysical paradigm (landscape aesthetics)

- Cognitive paradigm (landscape perception)

- Experiential paradigm (human-landscape interaction process)

These paradigms portray landscape research as multidisciplinary and holistic in nature. Perhaps, what is not clearly reflected in these paradigms is the aspect of landscape participatory governance. Zube et al. (1982) reveal that geographers, foresters, landscape architects, behavioural scientists and planners, among others, dominate landscape science. Based on the current state of the planet Earth, landscape science needs closer contact with other disciplines. Landscape scientists have distinguished themselves with the tradition of an integrated approach. This approach 
placed landscape science on a vantage point to respond to the Anthropocene challenges and opportunities offered by the Fourth Paradigm. Over time, landscape science has developed into a broad-based intersection of many disciplines (see Figure 3). This makes it a prominent player in the Anthropocene, data deluge and landscape sustainability discourse.

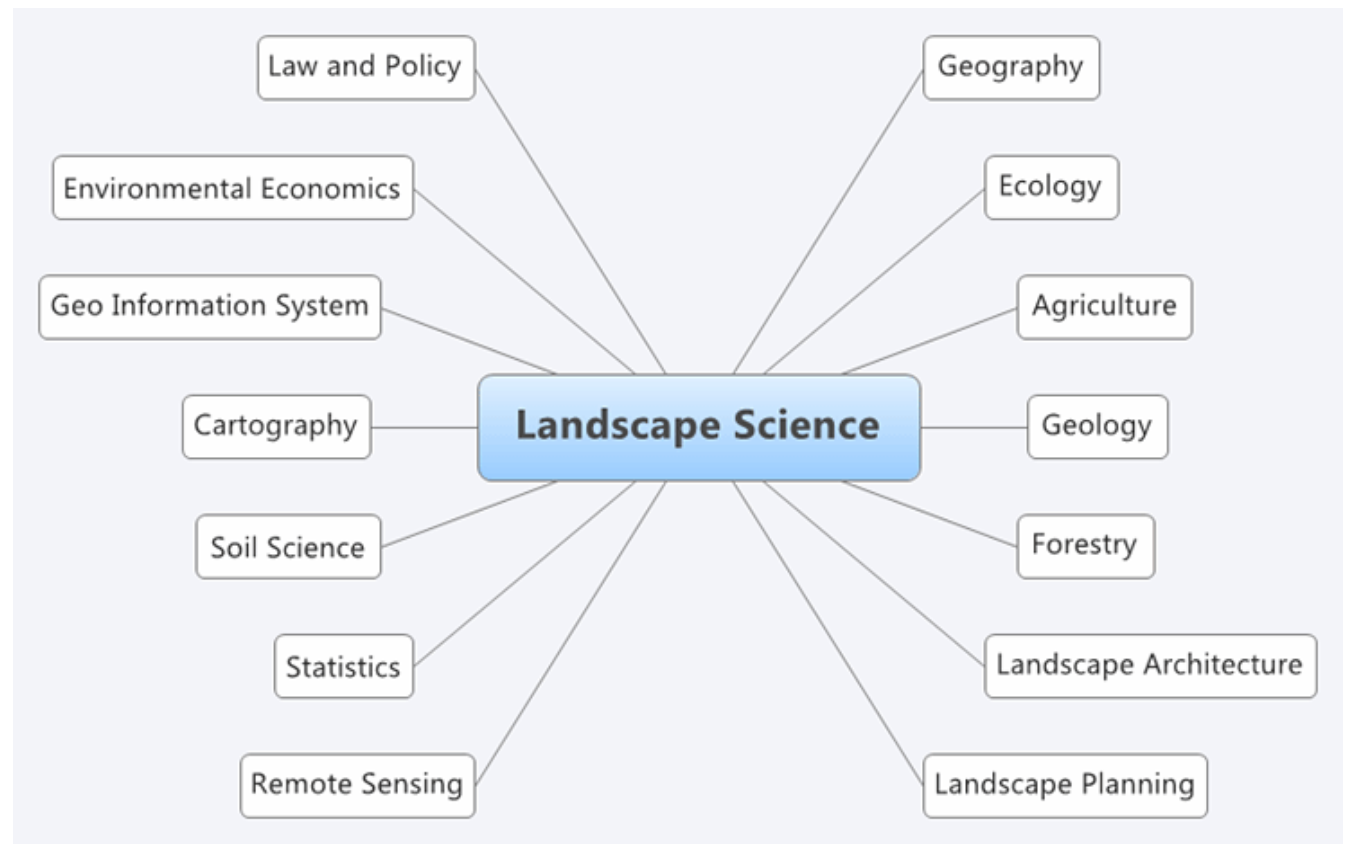

Figure 3: Landscape science in the 21st century agglomerates many disciplines.

Definitions of landscape are subject to the prevailing scientific atmosphere of a given society. For this reason, we examine some of the definitions of landscape at different times. We begin with Hartshorne (1939), who sees the landscape as an "external, visible (or touchable), surface of the earth." He adds that "this surface is formed by the outer surfaces, those in immediate contact with atmosphere, of vegetation, bare earth, snow, ice, or water bodies or the features made by man." Hartshorne tackles divisive arguments on landscape types by emphasising the terms "natural landscape" and "cultural landscape." He opines that the natural landscape is original and uninterrupted by humans, and refers to it as "primeval landscape." On the other hand, the scholar distinguishes cultural landscape as one with any notable alterations by "primitive or civilised man". Some landscape scientists are aware of what Hartshorne calls "notable alterations", and hence their focus is on ecological perspectives of landscapes. Today, natural landscapes by Hartshorne's definition are virtually nowhere to be seen. It is worth noting that we refer to Hartshorne's definition only in the context of the meaning of landscape. As a leading geographer, Hartshorne was obsessed with the idea of regionalism in geography, in contrast to Sauer's landscape school (Howe, 2011). Carl Sauer sought explanations of the deep and organic links between cultures and landscapes. Sauer's unique contribution to landscape science went beyond the meanings of landscapes. His ideas can still be used to chart a broader and integrated approach for managing landscape sustainability challenges. Mathewson (2011) observes that Sauer viewed landscape in the context of its visible material attributes, modification processes, plant and animal origin and dispersals, aboriginal depopulation, primitive and traditional agriculture, cultural diffusion and destructive exploitations. Sauer's "Morphology of Landscape" (1925) and his leadership of the Berkeley School of Cultural Geography created a niche for him in landscape science. The contemporary landscape 
challenges transcend borders of disciplines such as geography or countries like the United States. Hence, many disciplines use many terminologies to define the landscape. Terms such as geography, ecosystem, environment, planetary system, habitat, regions, scenery, nature or spatial systems are commonly used.

In 1939, Carl Troll, the father of landscape ecology, defined the landscape as "the total natural and human living space" (Naveh, 2007). Understanding the intricate relationship between humans and landscape prompted the emergence of landscape ecology. Carl Troll defines it as "the study of the main complex causal relationships between the life communities and their environment" which "are expressed regionally in a definite distribution pattern (landscape mosaic, landscape pattern)" (Troll, 1971). A more holistic paradigm is required to explain the cause and effect of landscape change. For this reason, Naveh and Lieberman introduced the Total Human Ecosystem (THE) paradigm in 1984. This paradigm, based on multidisciplinary landscape ecology, views landscape from its spatial, temporal, conceptual and hierarchical scales (Naveh and Lieberman, 1984). The authors maintain that THE considers "values of nature and its non-economic richness into workable parameters in educational and decision-making processes". It is on this basis that Naveh (2010) called the THE paradigm a social-ecological super system where humans, together with their total environment, form an indivisible and coherent co-evolutionary geo-bio-anthropological entity. However, as Zonneveld (1989) observes, the holistic perspective used in landscape science was borrowed from the physical sciences. Holism represents the hierarchy of all things - from quarks to minerals or from cells to a system. The main problem of this concept is that the system hierarchy "either remains the same over a certain period of time or shows a slow gradual change, without large, sudden changes." This situation negates the speed of changes that has recently affected landscapes. Scientific evidence on the impact of rapid landscape change underpins the need to embrace the Anthropocene debate from a broad perspective.

Based on the quest for sustainability landscape functions, government institutions also define landscapes holistically. The British government science think-tank, GO-Science suggests that, apart from pure ecological and socio-economic functions, landscape represents the historical, aesthetic, identity, heritage and mental well-being of a nation (Foresight Land Use Futures Project, 2010). Such institutions also recognise the role of public participation in landscape governance. The European Landscape Convention (ELC) stresses the role of people in its landscape policy formulation (ELC, 2004). This is a reflection of democratic principles in contemporary landscape management. The ELC also stresses the role of the awareness, planning, management and conservation of landscapes (Scott and Shannon, 2007; Scott, 2011; Llausàs and Nogué, 2012). Similar policies also exist for landscapes in the United States and Canada (Morse and Kujara, 2010). It is important to note that all the theories explained above recognise the role of humans, or at least the way in which humans perceive landscapes. However, perceptions have changed over time. The driving forces affecting landscape change also vary with time.

\section{Urbanisation and globalisation as the drivers of Anthro- pocene}

Urbanisation and globalisation are not independent of landscapes. The two processes are the leading symbols of the 21st century. It is important to examine how the two relate with the Anthropocene, big data and landscape sustainability. With half of the human race living in cities, the United Nations marked the 21st century as the urban century (Bogardi, 2008). According to Beaverstock et al. (2011), "the city is the global fulcrum for production, exchange and consumption." Mass consumption of natural resources is a trademark of urbanisation. Trends of urbanisation continue to soar, with differentials within and between various global regions. In Asia, the pace of urbanisation is between $100 \%$ in some countries, and 50 to $60 \%$ in others (Pod- 
dar, 2007; Yuen and Kong, 2009). Africa is also ranked one of the most urbanising regions, and $70 \%$ of its urban areas are designated as slums (UN-Habitat, 2003; World Bank, 2009). Similarly, Latin America and the Caribbean are rapidly urbanising at the rate of $80 \%$. These trends are embedded within threats of climate and land use change (Krellenberg et al., 2010). The rate of urbanisation underscores the intensity of pressure on the landscape within and around urban areas. Cities across continents and regions are linked to each other via economic and socio-ecological systems (Marcotullio, 2008; Sassen, 2009). Mega and large cities are located across ecological regions - drylands, rainforests, highlands and coastal zones. In terms of spatial size, by 2000, the size of the world's urban areas was around $2.8 \%$ of the world's total land area (SEDAC/CIESIN, 2005). Another estimate puts the size at around $0.3 \%$ of the earth's land mass (Martine, 2008).

Linking urbanisation and the Anthropocene, Meybeck and Vörösmarty (2005) observe that megacities cause global river fluxes. The authors characterise this as a feature of the Anthropocene. Urbanisation escalates land use and land cover change, carbon emission, and the redistribution of terrestrial energy (Stone Jr, 2009; Ellis, 2010; Dawson et al., 2010). Urban areas consume 70\% of the global net energy and its emissions (Seto and Satterthwaite, 2010). Cities also constitute most of the overarching means of earth modification through their intense material dependency (Kolbert, 2011). Proponents of the Anthropocene extend their debates to a number of major cities. Urban archaeologists argue that London, Istanbul, Beijing, Mexico City, Rome and Novgorod have traces of stratigraphic artificial grounds that reveal the onset of the Anthropocene (Edgeworth, 2010). Based on the above revelations, urbanisation can be considered as a hub that carries all other driving forces associated with the Anthropocene. The pressures that urbanisation exerts on the landscape could be studied through multiple types and forms of data.

Globalisation and urbanisation overlap each other due to their direct impact on landscape. Researchers find a strong correlation between the two processes, as illustrated by time-space telescoping theory and global city theory (Marcotullio et al., 2003; Marcotullio, 2005, 2008; Sassen, 2009). The two theories explain that globalisation deepens and intensifies urbanisation between countries. Globalisation, economic liberalisation and the presence of multinational corporations bring about rapid changes to the morphology of landscapes (Hamouche, 2004; Wilcox et al., 2011). In places, such as urbanised Singapore, industrial globalisation creates scenarios for urban spatial structuring (Zhu, 2002; Al Kuwari and Kaiser, 2011). This overlapping of the two processes breeds the concept of glurbanisation. Glurbanisation underscores the transformation of urban landscapes through the interconnectedness of cities and their patterns of resource consumption (Dalby, 2009; Hodson and Marvin, 2010). Globalisation makes the world more open and interconnected. Hence, Bradbury and Seymour (2008) conclude that the earth's transition to the Anthropocene is triggered by the force of globalisation. Allenby (2008) links cities, information and the Anthropocene through the interconnectedness of information and communication systems. On the other hand, Sassen (2009) argues that the global urban network is embedded within ecological implications. The concentration of population, industries and energy needs, and the culture of mass consumption of natural resources place cities at the heart of the Anthropocene debate. Based on the role of urban areas in the anthropocene debate, landscape scientists should focus on systematic landscape changes within and around cities. It is also important to measure the externalities or impacts of one city on the landscapes of other urban and rural areas to which they are connected through globalisation.

\section{State of the research: Landscape and the Anthropocene}

Landscape science has undertaken research into human impact on the landscape for centuries. Contemporary landscape scientists can build on this tradition to explore contemporary landscape changes associated with the Anthropocene debate. For example, the 19th century works of Lyell, 
Marsh and Stoppani and the 20th century work of Vemadsky and Le Roy all detail the domineering role of humans on landscapes (Crutzen and Stoermer, 2000). These scientists sensed the seriousness of human impact on the landscape in their respective times. According to Zalasiewicz et al. (2011), George Perkins Marsh raised concern in his Man and Nature (1864), while Antonio Stoppani coined the term Anthropozoic for landscape change; Svante Arrhenius and Thomas Chamberlain focused on increasing carbon concentrations. After World Wars I and II, scientists in Europe resuscitated the concept of noösphere, which stands for modifications to the earth system, referred to as the anthroposphere (Steffen et al., 2011). Although the scales of human impact vary in time and space, over the last 15,000 years, agriculture, energy and the export of raw materials remain the driving forces of land cover change (Armesto et al., 2010).

Ayestaran (2008) suggests that dealing with the challenges associated with the proposed Anthropocene should not be restricted to the sciences. Ethical, moral and philosophical considerations are also relevant. Massari (2010) and Tickell (2011) propose that political and social options are needed in addition to the technological solutions for tackling anthropocenic challenges. Thus, Anthropocene research ought to be transdisciplinary in nature. Hence it is essential to couple human, natural sciences and policy issues. Researchers use many tools and approaches, ranging from integrated land use models, coupled human and natural system, simulations and landscape metrics to investigate the physical, planning and management aspects of the landscape (Mitchell, 2006; Schaldach and Priess, 2008; Uuemaa et al., 2009; Haase and Schwarz, 2009; Jenerette and Potere, 2010). Apart from involving scientists, the Anthropocene debate also attracts the attention of the mass media. Several top global media - e.g., The Economist (2011), The New York Times (2011), Der Spiegel (Zalasiewicz, 2011), and the BBC (Falcon-Lang, 2011) - have addressed the Anthropocene debate.

To gain an overview of the current state of landscape research, we searched key science publication databases, namely the Web of Knowledge and Scopus. We extracted relevant publications on landscape and the Anthropocene from these sources. This method is common for landscape review articles (Meeus and Gulinck, 2008). Table 3 below reveals trends in Anthropocene and landscape research for the period from 1990 to 2011. Apparently, landscape research has grown extensively over the period compared to the Anthropocene. The former has generated in the region of tens of thousands of publications, while the latter has produced less than 200 peer-reviewed publications. The limitation of using this method is that only the most recent articles were retrievable. Many printed journals from the past were not included in these online databases.

\section{Fourth Paradigm and landscape research}

The world has changed tremendously through intensive technology data acquisition tools (Gray, 2009). By nature, landscape research is data intensive, and this makes it a strong stakeholder in the global data revolution. Most of the data for landscape queries come from the field and or through remotely sensed data platforms. Intensive and high-resolution data facilitate landscape research (Dozier, 2011; Perron and Fagherazzi, 2011). Undoubtedly, the new paradigm transforms the way in which landscape researchers search for and/or use data. Prior to this paradigm, scientific research thrived on three paradigms: empiricism, analysis, and simulation (Gray, 2009). Like its three predecessors, the Fourth Paradigm relies on the collection, curation, analysis and visualisation of data. Landscape researchers use theories or explanations (first paradigm); statistical, field and laboratory analyses (second paradigm) and computer-based simulation of landscapes (third paradigm). Therefore, there is no cause for alarm when landscape scientists adopt the new paradigm. Based on available records (Table 4), big data appears in some landscape-related disciplines, albeit to a small extent. In the opinion of Lynch (2009), the Fourth Paradigm provides an integrating framework that allows the first three paradigms (empiricism, analysis and simulation) 
Table 3: Landscape-Anthropocene Reasearch Trends

\begin{tabular}{|c|c|c|}
\hline Anthropocene Research & Web of Science & Scopus \\
\hline No. of publications & 139 & 160 \\
\hline Period & $1990-2011$ & $2008-2011$ \\
\hline Subject areas & $\begin{array}{l}\text { Environmental sciences/ecology } \\
(51) \text {, geology (12), science tech- } \\
\text { nology and others }(21) \text {, physical } \\
\text { geography (18), engineering (14) }\end{array}$ & $\begin{array}{l}\text { Environmental science }(63), \\
\text { earth and planetary sciences } \\
(60) \text {, agricultural and biologi- } \\
\text { cal sciences (45), social sciences } \\
(28) \text {, engineering (19) }\end{array}$ \\
\hline General categories & $\begin{array}{l}\text { Science technology, social sci- } \\
\text { ences, arts/humanities }\end{array}$ & - \\
\hline Document types & $\begin{array}{l}\text { Article }(90), \text { review }(20) \text {, letter } \\
(3), \text { meeting }(17) \text {, editorial }(17) \text {, } \\
\text { art and literature }(3), \text { book }(3), \\
\text { news }(1), \text { abstract }(1)\end{array}$ & $\begin{array}{l}\text { Article }(98) \text {, review }(22) \text {, confer- } \\
\text { ence paper }(17) \text {, editorial }(7) \text {, ar- } \\
\text { ticle in press }(5) \text {, note }(4) \text {, short } \\
\text { survey }(4) \text {, letter }(3) \text {, conference } \\
\text { review }(1)\end{array}$ \\
\hline Landscape Research & Web of Science & Scopus \\
\hline No. of publications & 90,468 & 96,930 \\
\hline Period & $1990-2011$ & $2008-2011$ \\
\hline Subject areas & $\begin{array}{l}\text { Environmental sciences/ecology } \\
(26,230) \text {, Geology }(7,801), \text { Physi- } \\
\text { cal geography }(6,258), \text { Geography } \\
(1,505) \text {, Urban studies (1,315), } \\
\text { Public administration (1) }\end{array}$ & $\begin{array}{l}\text { Environmental science }(38,188), \\
\text { Earth and planetary sciences } \\
(26,333) \text {, Agricultural and bio- } \\
\text { logical sciences }(23,892), \text { Social } \\
\text { sciences }(19,316), \text { Engineering } \\
(7,839)\end{array}$ \\
\hline Document types & $\begin{array}{l}\text { Article }(65,795), \text { review }(10, \\
603), \text { letter }(474), \text { meeting } \\
(11,151), \text { editorial }(1,724), \text { art } \\
\text { and literature }(6,542), \text { book } \\
(6,068), \text { news }(297), \text { abstract } \\
(760), \text { correction }(128), \text { biogra- } \\
\text { phy }(58), \text { patent }(5,468), \text { bibliog- } \\
\text { raphy }(8), \text { other }(8)\end{array}$ & $\begin{array}{l}\text { Article }(67,998), \text { review }(7,152) \text {, } \\
\text { conference paper }(9,257) \text {, article } \\
\text { in press }(1,178) \text {, short survey } \\
(571) \text {, editorial }(402) \text {, note }(405) \text {, } \\
\text { letter }(254) \text {, conference review } \\
(180) \text {, erratum }(135)\end{array}$ \\
\hline
\end{tabular}

Source: webofknowledge.com (Dec. 20, 2011) and scopus.com (Dec. 20, 2011) 
to be integrated and to reinforce one another. It is much easier to integrate the Fourth Paradigm with the others in landscape research. Landscape researchers are familiar with the use of datasets and landscape tools of analysis most of which are open access (see Tables 5 and 6 below). A data deluge is certainly one of the best ways to support peer-reviewed research. Tolle et al. (2011) opine that the Fourth Paradigm aids transparency and accountability in research production and dissemination.

Table 4: State of Fourth Paradigm Research

\begin{tabular}{lll}
\hline Fourth Paradigm & Web of Science & Scopus \\
\hline No. of publications & 04 & 09 \\
\hline Period & $2005-2011$ & $2005-2011$ \\
\hline Subject areas/category & $\begin{array}{l}\text { Engineering (1), Science and } \\
\text { technology (1), Environmental } \\
\text { sciences \& ecology; Physical ge- } \\
\text { ography (2) }\end{array}$ & $\begin{array}{l}\text { Environmental science (1), Earth } \\
\text { and planetary sciences (1), Agri- } \\
\text { cultural and biological sciences } \\
(1), \text { Arts and humanities (1), En- } \\
\text { gineering (5) }\end{array}$ \\
\hline Document types & $\begin{array}{l}\text { Editorial (1), book review (1), } \\
\text { article (2) }\end{array}$ & $\begin{array}{l}\text { Article (2), conference paper (3), } \\
\text { conference review (1), short sur- } \\
\text { vey (1) }\end{array}$ \\
\hline
\end{tabular}

Source: webofknowledge.com (Dec. 20, 2011) and scopus.com (Dec. 20, 2011) 
Table 5: Research Tools for Second, Third and Fourth Paradigms

\begin{tabular}{|c|c|c|c|}
\hline Satellite Images & $\begin{array}{l}\text { Landscape research } \\
\text { application scale }\end{array}$ & $\begin{array}{l}\text { Landscape analysis } \\
\text { tools }\end{array}$ & $\begin{array}{l}\text { Applications to } \\
\text { Landscape }\end{array}$ \\
\hline GeoEye-1 & Deep analysis & GIS packages, QGIS & $\begin{array}{l}\text { Analysis, visualisation, } \\
\text { mapping, modelling }\end{array}$ \\
\hline Worldview-1-2 & Deeper analysis & APACK & $\begin{array}{l}\text { Landscape metrics com- } \\
\text { putation }\end{array}$ \\
\hline Spot 1-5 & $\begin{array}{l}\text { Semi to detailed analy- } \\
\text { sis }\end{array}$ & Nature Serve Vista 2.0 & $\begin{array}{l}\text { Spatial planning deci- } \\
\text { sion support }\end{array}$ \\
\hline RapidEye & Deep analysis & Climate Wizard & $\begin{array}{l}\text { Statistical analysis of } \\
\text { past, current and future } \\
\text { climate variables }\end{array}$ \\
\hline EROS A-B & Deep analysis & $\begin{array}{l}\text { inVEST (Integrated } \\
\text { Valuation of Ecosystem } \\
\text { Services and Tradeoffs) }\end{array}$ & $\begin{array}{l}\text { Ecosystem services anal- } \\
\text { ysis }\end{array}$ \\
\hline Quickbird & Detailed analysis & Cellular Automata & $\begin{array}{l}\text { Modelling spatial di- } \\
\text { mensions }\end{array}$ \\
\hline IKONOS & Detailed analysis & FRAGSTATS & $\begin{array}{l}\text { Landscape fragmenta- } \\
\text { tion }\end{array}$ \\
\hline Landsat 1-7 & Semi detailed analysis & $\begin{array}{l}\text { ALARM (Assessing } \\
\text { Large Scale Risks for } \\
\text { Biodiversity with Tested } \\
\text { Methods) }\end{array}$ & $\begin{array}{l}\text { Landscape risk manage- } \\
\text { ment }\end{array}$ \\
\hline
\end{tabular}


Table 6: Databases for Second to Fourth Paradigms

\begin{tabular}{|c|c|c|c|}
\hline Landscape database & Source & Features & Functions/applications \\
\hline $\begin{array}{l}\text { C5 Landscape database } \\
\text { API } 2.0\end{array}$ & Open source & $\begin{array}{l}\text { Outdoor recreational } \\
\text { land use such as hunt- } \\
\text { ing, fishing, perfor- } \\
\text { mance art }\end{array}$ & $\begin{array}{l}\text { GIS based landscape } \\
\text { mapping, navigation, } \\
\text { analysis }\end{array}$ \\
\hline $\begin{array}{l}\text { LANMAP2 Pan- } \\
\text { European Landscape } \\
\text { Database }\end{array}$ & Open source & $\begin{array}{l}\text { Hierarchical classifica- } \\
\text { tion of } 350 \text { landscape } \\
\text { types from intertidal } \\
\text { flats, urban agglomera- } \\
\text { tions to water bodies }\end{array}$ & Mapping database \\
\hline $\begin{array}{l}\text { Therapeutic landscape } \\
\text { network }\end{array}$ & Open source & $\begin{array}{l}\text { Healthy and green } \\
\text { spaces }\end{array}$ & $\begin{array}{l}\text { Landscape and health } \\
\text { research }\end{array}$ \\
\hline GRID/GRUMP & $\begin{array}{l}\text { Open source / } \\
\text { CIESIN / SEDAC } \\
\text { / NASA }\end{array}$ & $\begin{array}{l}\text { World gridded popu- } \\
\text { lation / global urban } \\
\text { rural mapping }\end{array}$ & $\begin{array}{l}\text { Biodiversity manage- } \\
\text { ment }\end{array}$ \\
\hline $\begin{array}{l}\text { Vitour Landscape } \\
\text { Database }\end{array}$ & Open source & $\begin{array}{l}\text { Wine landscape conser- } \\
\text { vation and valorisation } \\
\text { in Europe }\end{array}$ & Landscape policy \\
\hline $\begin{array}{l}\text { What is Out There } \\
\text { Database }\end{array}$ & Open source & $\begin{array}{l}\text { Designed heritage land- } \\
\text { scapes from } 50 \text { states of } \\
\text { the US }\end{array}$ & $\begin{array}{l}\text { Cataloguing of historic } \\
\text { designed landscapes }\end{array}$ \\
\hline The Landscape Toolbox & $\begin{array}{l}\text { Open source } \\
\text { (USDA/Nature Con- } \\
\text { servancy) }\end{array}$ & $\begin{array}{l}\text { Abstracts of methods, } \\
\text { terms, and tools on } \\
\text { rangeland management }\end{array}$ & $\begin{array}{l}\text { Landscape research } \\
\text { tools }\end{array}$ \\
\hline Cultbase & $\begin{array}{l}\text { Open source / Eu- } \\
\text { ropean Commission } \\
2002-2005\end{array}$ & $\begin{array}{l}\text { European cultural land- } \\
\text { scapes and ecosystems }\end{array}$ & $\begin{array}{l}\text { Data for researchers, } \\
\text { students and public } \\
\text { users }\end{array}$ \\
\hline Atlas & $\begin{array}{l}\text { Open Source / } \\
\text { UNISCAPE, } 2005\end{array}$ & $\begin{array}{l}\text { Landscape higher edu- } \\
\text { cation in Europe }\end{array}$ & $\begin{array}{l}\text { Interactive website for } \\
\text { landscape education, } \\
\text { training and assessment }\end{array}$ \\
\hline $\begin{array}{l}209 \text { Database Manage- } \\
\text { ment System }\end{array}$ & $\begin{array}{l}\text { Open source / Na- } \\
\text { tional Centre for } \\
\text { Landscape Fire } \\
\text { Analysis }\end{array}$ & $\begin{array}{l}\text { Landscape fire inci- } \\
\text { dences }\end{array}$ & $\begin{array}{l}\text { Wild fire incident man- } \\
\text { agement }\end{array}$ \\
\hline $\begin{array}{l}\text { European Digital } \\
\text { Archive on Soil Maps } \\
\text { of the World }\end{array}$ & $\begin{array}{l}\text { Open source / EC } \\
\text { Directorate Gener- } \\
\text { ate Joint Research } \\
\text { Centre }\end{array}$ & Land use and soils & Land use, soils \\
\hline
\end{tabular}


Table 6 - Continued

\begin{tabular}{|c|c|c|c|}
\hline Landscape database & Source & Features & Functions/applications \\
\hline $\begin{array}{l}\text { Global Spatial Database } \\
\text { of Agricultural Land-use } \\
\text { Statistics }\end{array}$ & Open source/FAO & Agricultural land uses & Land use and land cover \\
\hline Open Landscapes & Open access / ZALF & Landscape science & $\begin{array}{l}\text { Primary data, meta- } \\
\text { data, methods, wiki }\end{array}$ \\
\hline TERRASTAT database & Open source / FAO & $\begin{array}{l}\text { Land resource potentials } \\
\text { and constraints poten- } \\
\text { tials }\end{array}$ & $\begin{array}{l}\text { Statistical data on agro } \\
\text { allied land uses }\end{array}$ \\
\hline $\begin{array}{l}\text { Earth System Science } \\
\text { Data }\end{array}$ & $\begin{array}{l}\text { Open source / } \\
\text { Copernicus Publi- } \\
\text { cations }\end{array}$ & $\begin{array}{l}\text { Earth system science } \\
\text { data }\end{array}$ & Datasets \\
\hline PANGAEA & $\begin{array}{l}\text { Open access / Alfred } \\
\text { Wegener Institute } \\
(\mathrm{AWI})\end{array}$ & $\begin{array}{l}\text { Georeferenced data } \\
\text { from earth system re- } \\
\text { search }\end{array}$ & $\begin{array}{l}\text { Earth system research } \\
\text { data }\end{array}$ \\
\hline Geo When Database & $\begin{array}{l}\text { Open source / Uni- } \\
\text { versity of California } \\
\text { at Berkeley }\end{array}$ & $\begin{array}{l}\text { Geologic landscapes } \\
\text { based on timescales }\end{array}$ & $\begin{array}{l}\text { Landscape age specifica- } \\
\text { tions }\end{array}$ \\
\hline $\begin{array}{l}\text { USDA/ERS Major } \\
\text { Land Uses }\end{array}$ & $\begin{array}{l}\text { Open access / } \\
\text { USDA }\end{array}$ & $\begin{array}{l}\text { Major land uses (pub- } \\
\text { lic/private in the US) } \\
\text { based on agricultural } \\
\text { census }\end{array}$ & $\begin{array}{l}\text { Land uses from } 1945 \text { to } \\
2007\end{array}$ \\
\hline
\end{tabular}

With multiple sources of landscape data, researchers are given a new opportunity to observe landscapes simultaneously and squarely (Lehning et al., 2009). Similarly, Hunt et al. (2009) add that for the benefit of landscape and ecological research, the Fourth Paradigm synthesises ground data, remote sensing, internet connectivity and commodity computing, and the navigational ability of the data cyber-infrastructure. The capacity of this data-driven approach is particularly enlightening for complex ecological systems (Kelling et al., 2009). It is worth noting that even pioneer Fourth Paradigm literature (e.g., Hey, 2010) sees the potentials of physical sciences such as biology, astronomy, particle physics, environmental science, oceanography, as well as humanities and social sciences. Most of these disciplines are directly or indirectly related to landscape science and research interests.

The new paradigm is welcomed by leading international science hubs. The National Science Foundation supports it through its DataONE and Data Conservancy projects (Lagoze and Patzke, 2011). Institutional repositories also facilitate data sharing, scrutiny, collaboration and the discovery of older data sets (Nelson, 2009). The author maintains that what restricts the smooth use of big data projects across the world are the doubts concerning data precision, storage formats, suspicion by scientists and cloudy legal infrastructures. Apart from these, the worst threat is the external threat from intrusion attempts, hacking and cybercrimes (Perkel, 2010). Some of the challenges associated with the Fourth Paradigm extend to environmental data. Some data owners consider whether data should be used to measure indicators or to solve environmental crises (Goldston, 2008). In other words, it is feared that data could be used against the interests of its owners. For instance, industries could fear to release data on their pollutants. 


\section{Discussion}

In this paper, we try to link the Anthropocene, the Fourth Paradigm and landscape sustainability. Based on the literature, we suggest that urbanisation and globalisation are core drivers of landscape change associated with the proposed Anthropocene. The Anthropocene debate also creates an avenue for landscape researchers to further understand the depths of human impact on urban landscapes. The anthropogenisation of the planet is what the Anthropocene represents (Zalasiewicz et al., 2008). Scientists continue to argue on the timing and ratification of the term (Ruddiman, 2003; Meybeck, 2003; Schlütz and Lehmkuhl, 2009). The arguments may persist until the final decision is taken by ICS. Nevertheless, scientists with a stake in landscapes have shown solidarity with the Anthropocene idea and what it stands for. From the prestigious Nobel Prize awarded to Crutzen to the unlimited peer-reviewed publications, conferences, and so on. The Anthropocene has experienced broad scientific and public acceptance.

This article identifies globalisation and urbanisation as the key driving forces of the Anthropocene. This is based on an attempt to ascertain the critical rather than the general drivers of the proposed Anthropocene contrary to the conceptualisation of the term based on other sources of pressures (Crutzen, 2002; Lövbrand et al., 2009; Zalasiewicz et al., 2008, 2011, etc.). One of the limitations of this article is that it assumes that industrialisation is an integral part of urbanisation and globalisation. This may not be acceptable to some researchers. Although industrialisation is closely tied to the needs of the urban population, its role is enormous in the proposed Anthropocene epoch. Further studies are required to explore the role of this driving force of Anthropocene. Should it be ratified, Anthropocene could be measured in terms of human imprints on planetary boundaries. In relation to this, it is important to establish connections between population pressure and landscape change at the urban level. This article focuses on the modern scientific explanations of landscape. Studies on indigenous landscape perceptions may reveal alternative perspectives on meanings of landscape. There are many landscape cultural perspectives around the world. Even the European Landscape Convention recognises people's perception of the landscape (Antrop, 2005; Llausàs and Nogué, 2012).

This article's main argument is that globalisation and urbanisation are the leading driving force behind the proposed Anthropocene. However, these processes are more intensive and rapid in developing countries (Marcotullio, 2001; Marcotullio et al., 2003; Marcotullio, 2008). Incidentally, these countries are considerably lagging behind in substantive landscape policies. Problems could be understood more thoroughly using data resources offered by the Fourth Paradigm. In this way, landscape science can provide leadership for interdisciplinary research. As a meta-discipline, landscape science recognises social and ecological parameters (Schaldach and Priess, 2008; Uuemaa et al., 2009) and policy issues (Massari, 2010). As a result, the Fourth Paradigm would greatly help landscape researchers from data deficient areas to acquire free data for use in solving local and regional challenges. Big data could facilitate better planning to respond to environmental crises such as flooding, sundry human and natural disasters. Without this revolution and the anticipated use of the raw data material, the future crises would be very complex. Poor data affects our understanding of land use, climate, ecosystem and other critical issues (Dozier, 2011).

Living Reviews in Landscape Research

http: //www. livingreviews . org/lrlr-2012-1 


\section{Conclusions}

In the Fourth Paradigm era, landscape research would be more transparent, more global and local in nature and richer in data diversity and availability. This gives landscape science an edge over most other disciplines. The significance of coupling the Fourth Paradigm, the Anthropocene and landscape science is to create an opportunity for researchers to develop local and global insights to improve population-environment well-being. For example, Europe builds diverse and substantial landscape databases, used effectively for sustainable spatial decision-making. Landscape researchers would benefit from more detailed global mapping and other spatial databases. However, local data acquisition in developing countries remains a great challenge. The planning and documentation of data is a precursor to all effective and sustainable spatial planning. Data collection is also the bedrock from which landscape policies would emerge. The success of landscape research in Europe and North America has its roots in enhanced data collection and management. Organisations such as the International Association for Landscape Ecology (IALE) and the Society for Urban Ecology (SURE) should take a lead in setting data agenda for more landscape-centred arguments on landscapes in the Anthropocene. Landscape research and policy can only succeed if the global public is well informed. We also believe that universities and associated institutions, funding agencies, governments, researchers and industry are key players in data production, policy and dissemination.

\section{Acknowledgements}

Special thanks go to Prof. Marc Antrop for providing some of the articles used for this paper. The first author would like to thank IALE for its travel award for the 8th IALE congress in Beijing. The idea for this review arose after meeting Dr. Claus Dalchow at the congress. The two anonymous reviewers and language editor share all the credits of this article with us. Their suggestions were highly constructive and instructive. 


\section{References}

Al Kuwari, N.Y. and Kaiser, M.F. (2011), "Impact of North Gas Field development on landuse/landcover changes at Al Khore, North Qatar, using remote sensing and GIS", Applied Geography, 31: 1144-1153, [DOI]. (Cited on page 13.)

Allenby, B. (2008), "The Anthropocene as Media: Information Systems and the Creation of the Human Earth", American Behavioral Scientist, 52(1): 107-140, [DOI]. (Cited on page 13.)

Anthropocene Working Group, "What is the 'Anthropocene'? current definition and status", project homepage, Subcommission of Quaternary Stratigraphy of the International Commission on Stratigraphy (ICS). URL (accessed 22 February 2012): http://www.quaternary.stratigraphy.org.uk/workinggroups/Anthropocene/. (Cited on page 7.)

Antrop, M. (2000a), "Geography and landscape science", in 29th International Geographical Congress, Belgeo, Special Issue, pp. 9-35, Heverlee (SRBG). (Cited on page 5.)

Antrop, M. (2000b), "Background concepts for integrated landscape analysis", Agriculture, Ecosystems $E^{6}$ Environment, 77(1-2): 17-28, [DOI]. (Cited on page 5.)

Antrop, M. (2005), "Why landscapes of the past are important for the future", Landscape and Urban Planning, 70(1-2): 21-34, [DOI]. (Cited on page 20.)

Armesto, J.J., Manuschevich, D., Mora, A., Smith-Ramirez, C., Rozzi, R., Abarzúa, A.M. and Marquet, P.A. (2010), "From the Holocene to the Anthropocene: A historical framework for land cover change in southwestern South America in the past 15,000 years", Land Use Policy, 27: 148-160, [DOI]. (Cited on page 14.)

Austin, S.A. (2009), "The dynamic landscape on the north flank of Mount St. Helens", in O'Connor, J.E., Dorsey, R.J. and Madin, I.P., eds., Volcanoes to Vineyards: Geologic Field Trips through the Dynamic Landscape of the Pacific Northwest, Field Guide, 15, pp. 337-344, Boulder, CO (Geological Society of America). (Cited on page 10.)

Ayestaran, I. (2008), "The second Copernican revolution in the Anthropocene: an overview", Revista Internacional Sostenibilidad, Tecnología y Humanismo, 3: 145-157. URL (accessed 3 July 2012): http://hdl.handle.net/2099/7083. (Cited on page 14.)

Beaverstock, J.V., Faulconbridge, J.R. and Hoyle, M. (2011), "Globalisation and the City", in Leyshon, A., Lee, R., McDowell, L. and Sunley, P., eds., The SAGE Handbook of Economic Geography, pp. 189-201, London (SAGE). (Cited on page 12.)

Bogardi, J.J. (2008), "Foreword", in Bohle, H.-G. and Warner, K., eds., Megacities: Resilience and Social Vulnerability, SOURCE, 10, p. 7, Bonn (UNU-EHS). URL (accessed 3 July 2012): http://www.ehs. unu.edu/article/read/566. (Cited on page 12.)

Boyle, J.F., Gaillard, M.-J., Kaplan, J.O. and Dearing, J.A. (2011), "Modelling prehistoric land use and carbon budgets: A critical review", The Holocene, 21(5): 715-722, [DOI]. (Cited on page 10.)

Bradbury, R. and Seymour, R. (2008), "Plan B for the Anthropocene", 11th International Coral Reef Symposium, Ft. Lauderdale, Florida, July 7-11, 2008, conference paper. Online version (accessed 3 July 2012):

http://www.nova.edu/ncri/11icrs/ms23_orals.html. (Cited on page 13.)

Cosgrove, D. (2004), "Landscape and Landschaft", Bulletin of the GHI, 35: 57-71. URL (accessed 3 July 2012):

http://www.ghi-dc.org/publications/ghipubs/bu/035/35.57.pdf. (Cited on page 5.)

Crutzen, P.J. (2002), "Geology of mankind", Nature, 415: 23, [DOI]. (Cited on pages 7 and 20.) 
Crutzen, P.J. and Stoermer, E.F. (2000), "The 'Anthropocene"', Global Change Newsletter, 41, Stockholm (IGBP). Online version (accessed 3 July 2012):

http://www.igbp.net/download/18.316f18321323470177580001401/NL41.pdf. (Cited on page 14.)

Dalby, S. (2009), "Anthropocene Security", ISA 50th Annual Convention 'Exploring the Past, Anticipating the Future', New York, February 15-18, 2009, conference paper. Online version (accessed 9 July 2012): http://www.allacademic.com/meta/p310533_index.html. (Cited on page 13.)

Dawson, R., Hall, J., Walsh, C., Barker, T., Barr, S., Batty, M., Bristow, A., Burton, A., Carney, S., Dagoumas, A., Evans, S., Ford, A., Glennis, V., Goodess, C., Harpham, C., Harwatt, H., Kilsby, C., Köhler, J., Jones, P., Manning, L., McCarthy, M., Sanderson, M., Tight, M., Timms, P. and Zanni, A. (2010), "The Tyndall Centre's Urban Integrated Assessment Facility", UGEC Viewpoints, 3, Tempe, AZ (Urbanization and Global Environmental Change (UGEC)). Online version (accessed 3 July 2012): http://www. ugec.org/tiki-index.php?page=Viewpoints. (Cited on page 13.)

Dozier, J. (2011), "Mountain hydrology, snow color, and the fourth paradigm", Eos, Transactions AGU, 92(43): 373-378, [DOI]. (Cited on pages 14 and 20.)

Dutch, S. (1999), "Erosion and Landscape Evolution", personal homepage, University of Wisconsin-Green Bay. URL (accessed 5 July 2012): http://www. uwgb.edu/dutchs/earthsc202notes/erosion.htm. (Cited on page 8.)

Edgeworth, M. (2010), "Archaeologists should grapple with the Anthropocene too...", online resource, Archaeolog. URL (accessed 5 July 2012):

http://traumwerk.stanford.edu/archaeolog/2010/06/archaeologists_should_grapple.html. (Cited on page 13.)

"The European Landscape Convention" (2004), institutional homepage, Council of Europe. URL (accessed 3 July 2012):

http://www.coe.int/t/dg4/cultureheritage/heritage/Landscape/. (Cited on page 12.)

Ellis, E. (2010), "Land-use and land-cover change", in Cleveland, C.J., ed., The Encyclopedia of Earth, Washington, DC (Environmental Information Coalition, National Council for Science and the Environment). URL (accessed 13 March 2011):

http://www. eoearth.org/article/Land-use_and_land-cover_change. (Cited on page 13.)

Ellis, E.C. (2011), "Anthropogenic transformation of the terrestrial biosphere", Philosophical Transactions of the Royal Society of London, Series A, 369(1938): 1010-1035, [DOI]. (Cited on page 10.)

Ellis, E.C. and Haff, P.K. (2009), "Earth Science in the Anthropocene: New Epoch, New Paradigm, New Responsibilities", Eos, Transactions AGU, 90(49): 473, [DOI]. (Cited on page 7.)

Ellis, E.C. and Ramankutty, N. (2008), "Putting people in the map: anthropogenic biomes of the world", Frontiers in Ecology and the Environment, 6(8): 439-447, [DOI]. (Cited on page 10.)

Ellis, E.C., Goldewijk, K.K., Siebert, S., Lightman, D. and Ramankutty, N. (2010), "Anthropogenic transformation of the biomes, 1700 to 2000", Global Ecology and Biogeography, 19(5): 589-606, [DOI]. (Cited on page 10.)

Falcon-Lang, H. (2011), "Anthropocene: Have humans created a new geological age?", online resource, BBC News. URL (accessed 5 July 2012):

http://www.bbc.co.uk/news/science-environment-13335683. (Cited on page 14.)

Falkowski, P.G., Algeo, T., Codispoti, L., Deutsch, C., Emerson, S., Hales, B., Huey, R.B., Jenkins, W.J., Kump, L.R., Levin, L.A., Lyons, T.W., Nelson, N.B., Schofield, O.S., Summons, R., Talley, L.D., Thomas, E., Whitney, F. and Pilcher, C.B. (2011), "Ocean deoxygenation: Past, present, and future", Eos, Transactions $A G U, 92(46)$ : 409-410, [DOI]. (Cited on page 10.) 
Foresight Land Use Futures Project (2010), "Land Use Futures: Making the most of the land in the 21st century. Final Project Report", London (The Government Office for Science). Online version (accessed 3 July 2012):

http://www.bis.gov.uk/foresight/our-work/projects/published-projects/land-use-futures/ reports-and-publications. (Cited on page 12.)

Galaz, V., Biermann, F., Crona, B., Loorbach, D., Folke, C., Olsson, P., Nilsson, M., Allouche, J., Persson, A. and Reischl, G. (2012), "'Planetary boundaries' - exploring the challenges for global environmental governance", Current Opinion in Environmental Sustainability, 4(1): 80-87, [DOI]. (Cited on page 7.)

Goldston, D. (2008), "Big data: Data wrangling", Nature, 455: 15, [DOI]. (Cited on page 19.)

Gray, J. (2009), "Jim Gray on eScience: A Transformed Scientific Method", in Hey, T., Tansley, S. and Tolle, K., eds., The Fourth Paradigm: Data-Intensive Scientific Discovery, pp. xuii-xxxi, Redmond, WA (Microsoft Research). Online version (accessed 3 July 2012): http://research.microsoft.com/en-us/collaboration/fourthparadigm/contents.aspx. (Cited on page 14.)

Grayson, D.K. (2008), "Holocene Underkill", Proceedings of the National Academy of Sciences of the USA, 105(11): 4077-4078, [DOI]. (Cited on page 7.)

Haase, D. and Schwarz, N. (2009), "Simulation Models on Human-Nature Interactions in Urban Landscapes: A Review Including Spatial Economics, System Dynamics, Cellular Automata and Agent-based Approaches", Living Reviews in Landscape Research, 3(2). URL (accessed 11 December 2011): http://www.livingreviews.org/lrlr-2009-2. (Cited on page 14.)

Hack, J.T. (1960), "Interpretation of Erosional Topography in Humid Temperate Regions", American Journal of Science, 258-A: 80-97. Online version (accessed 3 July 2012): http://earth.geology.yale.edu/ ajs/BradleyVol.html. (Cited on page 8.)

Hamouche, M.B. (2004), "The changing morphology of the gulf cities in the age of globalisation: the case of Bahrain", Habitat International, 28(4): 521-540, [DOI]. (Cited on page 13.)

Hartshorne, R. (1939), "The Nature of Geography, A critical survey of current thought in the light of the past (reprinted with corrections 1989)", Annals of the Association of American Geographers, 29: 3-4. (Cited on page 11.)

Hey, T. (2010), "The Fourth Paradigm: Data Intensive Scientific Discovery", in Tuominen, K., ed., From Information to Innovation: ICSTI Annual Conference, VTT Symposium 267, Helsinki, June 10-11, 2010, pp. 235-259, Espoo, Finland (Julkaisija-Utgivare). Online version (accessed 3 July 2012): http://www.vtt.fi/publications/index.jsp. (Cited on page 19.)

Hey, T. (2011), "e-Science and the Fourth Paradigm: Data Intensive Scientific Discovery and Digital Preservation", APA Conference, London, 8-9 November 2011, conference paper. Online version (accessed 3 July 2012):

http://www .alliancepermanentaccess.org/index.php/knowledge-base/member-resources/ documents-and-downloads/?did=78. (Cited on page 5.)

Hodson, M. and Marvin, S. (2010), "Urbanism in the anthropocene: Ecological urbanism or premium ecological enclaves?", City, 14(3): 298-313, [DOI]. (Cited on page 13.)

Howe, N. (2011), "Landscape Versus Region: Part I", in Agner, J.A. and Ducan, J.S., eds., The WileyBlackwell Companion to Human Geography, pp. 114-129, Chichester (John Wiley), [DOI]. (Cited on page 11.)

Hunt, J.R., Baldocchi, D.D. and van Ingen, C. (2009), "Redefining Ecological Science Using Data", in Hey, T., Tansley, S. and Tolle, K., eds., The Fourth Paradigm: Data-Intensive Scientific Discovery, pp. 21-26, Redmond, WA (Microsoft Research). Online version (accessed 3 July 2012): http://research.microsoft.com/en-us/collaboration/fourthparadigm/contents.aspx. (Cited on page 19.) 
Jenerette, G.D. and Potere, D. (2010), "Global analysis and simulation of land-use change associated with urbanization", Landscape Ecology, 25(5): 657-670, [DOI]. (Cited on page 14.)

Kelling, S., Hochachka, W.M., Fink, D., Riedewald, M., Caruana, R., Ballard, G. and Hooker, G. (2009), "Data-Intensive Science: A New Paradigm for Biodiversity Studies", BioScience, 59(7): 613-620. Online version (accessed 4 July 2012):

http://www.bioone.org/toc/bisi/59/7. (Cited on page 19.)

Kolbert, E. (2011), "Enter Anthropocene Age - Age of Man", National Geographic, 2011(March). Online version (accessed 4 July 2012):

http://ngm.nationalgeographic.com/2011/03/age-of-man/kolbert-text. (Cited on page 13.)

Krellenberg, K., Heinrichs, D. and Barton, J. (2010), "Climate Change and Adaptation Strategies in Latin American City-Regions: The Case of Santiago de Chile", UGEC Viewpoints, 3, Tempe, AZ (Urbanization and Global Environmental Change (UGEC)). Online version (accessed 4 July 2012): http://www . ugec.org/tiki-index.php?page=Viewpoints. (Cited on page 13.)

Kuhn, T.S. (1970), The Structure of Scientific Revolutions, Chicago (University of Chicago Press), 2nd edn. (Cited on page 5.)

Lagoze, C. and Patzke, K. (2011), "A research agenda for data curation cyberinfrastructure", in Proceedings of the 11th ACM/IEEE Joint Conference on Digital Libraries (JCDL 2011), Ottawa, ON, Canada, June $13-17,2011$, pp. 373-382, New York (ACM), [DOI]. Online version (accessed 5 July 2012): http://jcdl.org/archived-conf-sites/jcdl2011/full-papers.html. (Cited on page 19.)

Lehning, M., Dawes, N., Bavay, M., Parlange, M., Nath, S. and Zhao, F. (2009), "Instrumenting the Earth: Next-Generation Sensor Networks and Environmental Science", in Hey, T., Tansley, S. and Tolle, K., eds., The Fourth Paradigm: Data-Intensive Scientific Discovery, pp. 45-51, Redmond, WA (Microsoft Research). Online version (accessed 3 July 2012):

http://research.microsoft.com/en-us/collaboration/fourthparadigm/contents.aspx. (Cited on page 19.)

Li, S., Chang, Q., Peng, J. and Wang, Y. (2009), "Indicating landscape fragmentation using L-Z complexity", Ecological Indicators, 9(4): 780-790, [DOI]. (Cited on page 10.)

Llausàs, A. and Nogué, J. (2012), "Indicators of landscape fragmentation: The case for combining ecological indices and the perceptive approach", Ecological Indicators, 15(1): 85-91, [DOI]. (Cited on pages 12 and 20.)

Lövbrand, E., Stripple, J. and Wiman, B. (2009), "Earth System governmentality: Reflections on science in the Anthropocene", Global Environmental Change, 19(1): 7-13, [DOI]. (Cited on pages 5, 6, and 20.)

Lynch, C. (2009), "Jim Gray's Fourth Paradigm and the Construction of the Scientific Record", in Hey, T., Tansley, S. and Tolle, K., eds., The Fourth Paradigm: Data-Intensive Scientific Discovery, pp. 177-183, Redmond, WA (Microsoft Research). Online version (accessed 3 July 2012):

http://research.microsoft.com/en-us/collaboration/fourthparadigm/contents.aspx. (Cited on page 14.)

Marcotullio, P.J. (2001), "The compact city, environmental transition theory and Asia-Pacific urban sustainable development", International Workshop "New Approaches to Land Management for Sustainable Urban Regions', University of Tokyo, Japan 29-31 October 2001, conference paper. Online version (accessed 3 July 2012):

http://up.t.u-tokyo.ac.jp/SUR/papers.html. (Cited on page 20.)

Marcotullio, P.J. (2005), "Time-Space Telescoping and Urban Environmental Transitions in the Asia Pacific", Yokohama (UNU-IAS). Online version (accessed 4 July 2012):

http://www.ias.unu.edu/binaries2/Telescoping.pdf. (Cited on page 13.) 
Marcotullio, P.J. (2008), "Globalization and urban environmental change in the Asia Pacific Region", United Nations Expert Group Meeting on Population Distribution, Urbanization, Internal Migration and Development, New York, 21-23 January 2008, conference paper. Online version (accessed 4 July 2012):

http://www.un.org/esa/population/meetings/EGM_PopDist/EGM_PopDist.htm. (Cited on pages 13 and 20.)

Marcotullio, P.J., Rothenberg, S. and Miri, N. (2003), "Globalization and urban environmental transitions: Comparison of New York's and Tokyo's experiences", Annals of Regional Science, 37(3): 369-390, [DOI]. (Cited on pages 13 and 20.)

Martine, G. (2008), "Preparing for Sustainable Urban Growth in Developing Areas", United Nations Expert Group Meeting on Population Distribution, Urbanization, Internal Migration and Development, New York, 21-23 January 2008, conference paper. Online version (accessed 4 July 2012): http://www.un.org/esa/population/meetings/EGM_PopDist/EGM_PopDist.htm. (Cited on page 13.)

Massari, P. (2010), "The speedup of climate change", online resource, Harvard University. URL (accessed 4 July 2012):

http://news.harvard.edu/gazette/story/2010/08/the-speedup-of-climate-change/. (Cited on pages 14 and 20.)

Mathewson, K. (2011), "Landscape Versus Region - Part II", in Agnew, J.A. and Ducan, J.S., eds., The Wiley-Blackwell Companion to Human Geography, pp. 130-145, Oxford, UK (Wiley-Blackwell), [DOI]. (Cited on page 11.)

Meadows, D.K., Croissant, C. and York, A.M. (2005), "Land use policy and landscape fragmentation in an urbanizing region: Assessing the impact of zoning", Applied Geography, 25(2): 121-141, [DOI]. (Cited on page 10.)

Meadows, M.E (2001), "The role of Quaternary environmental change in the evolution of landscapes: case studies from southern Africa", Catena, 42(1): 39-57, [DOI]. (Cited on page 8.)

Meeus, S.J. and Gulinck, H. (2008), "Semi-Urban Areas in Landscape Research: A Review", Living Reviews in Landscape Research, 2(3). URL (accessed 12 October 2011):

http://www.livingreviews.org/lrlr-2008-3. (Cited on page 14.)

Meybeck, M. (2003), "Global analysis of river systems: from Earth system controls to Anthropocene syndromes", Philosophical Transactions of the Royal Society of London, Series B, 358(1440): 19351955, [DOI]. (Cited on pages 7 and 20.)

Meybeck, M. and Vörösmarty, C. (2005), "Fluvial filtering of land-to-ocean fluxes: from natural Holocene variations to Anthropocene", Comptes Rendus Geoscience, 337(1-2): 107-123, [DOI]. (Cited on page 13.)

Mitchell, J.K. (2006), "Urban Disasters as Indicators of Global Environmental Change: Assessing Functional Varieties of Vulnerability", in Ehlers, E. and Krafft, T., eds., Earth System Science in the Anthropocene, pp. 135-152, Berlin (Springer). (Cited on page 14.)

Morse, C.E. and Kujara, R. (2010), "Strategies for Promoting Working Landscapes in North America and Europe: A Report for the Vermont Council on Rural Development", Montpelier, VT (Vermont Council on Rural Development). Online version (accessed 5 July 2012):

http://vtworkinglands.org/sites/default/files/library/files/workinglandscape/

WLActionPlan-final-sm.pdf. (Cited on page 12.)

Nature Editorial (2011), "The human epoch: Official recognition for the Anthropocene would focus minds on the challenges to come", online resource, Nature, [DOI]. URL (accessed 3 July 2012):

http://www.nature.com/nature/journal/v473/n7347/full/473254a.html. (Cited on page 7.) 
Naveh, Z. (2007), "The transformation of landscape ecology and restoration ecology into transdisciplinary sciences of holistic landscape study, management and planning, conservation and restoration", in Transdisciplinary Challenges in Landscape Ecology and Restoration Ecology - An Anthology, Landscape Series, 7, pp. 353-402, Dordrecht (Springer). (Cited on pages 5 and 12.)

Naveh, Z. (2010), "Ecosystem and landscapes - a critical comparative appraisal", Journal of Landscape Ecology, 3(1): 64-81. Online version (accessed 5 July 2012): http://www.iale.cz/downloads/JLE_5/6_Naveh.pdf. (Cited on page 12.)

Naveh, Z. and Lieberman, A.S. (1984), Landscape Ecology Theory and Application, New York (Springer). (Cited on page 12.)

Nelson, B. (2009), "Data sharing: Empty archives", Nature, 461: 160-163, [DOI]. (Cited on page 19.)

NYT Editorial (2011), "The Anthropocene", online resource, The New York Times. URL (accessed 5 July 2012):

http://www.nytimes.com/2011/02/28/opinion/28mon4.html/. (Cited on page 14.)

Perkel, J. (2010), "Cybersecurity: How safe are your data?", Nature, 464: 1260-1261, [DOI]. (Cited on page 19.)

Perron, J.T. and Fagherazzi, S. (2011), "The legacy of initial conditions in landscape evolution", Earth Surface Processes and Landforms, 37(1): 52-63, [DOI]. (Cited on page 14.)

Poddar, T. (2007), "India's urbanization: Emerging opportunities", Jersey City, NJ (Goldman Sachs). Online version (accessed 5 July 2012):

http://www.goldmansachs.com/our-thinking/topics/brics/india-urbanization.html. (Cited on page 12.)

Raupach, M.R. and Canadell, J.G (2010), "Carbon and the Anthropocene", Current Opinion in Environmental Sustainability, 2(4): 210-218, [DOI]. (Cited on page 10.)

Research Data Strategy Working Group (2011), "Mapping the Data Landscape: Report of the 2011 Canadian Research Data Summit", Ottawa (NRC-CISTI). Online version (accessed 12 March 2012):

http://rds-sdr.cisti-icist.nrc-cnrc.gc.ca/eng/events/data_summit_2011/. (Cited on page 5.)

Robin, L. and Steffen, W. (2007), "History for the Anthropocene", History Compass, 5(5): 1694-1719, [DOI]. (Cited on page 7.)

Rockström, J., Steffen, W., Noone, K., Persson, Å., Chapin III, F.S., Lambin, E.F., Lenton, T.M., Scheffer, M., Folke, C., Schellnhuber, H.J., Nykvist, B., de Wit, C.A., Hughes, T., van der Leeuw, S., Rodhe, H., Sörlin, S., Snyder, P.K., Costanza, R., Svedin, U., Falkenmark, M., Karlberg, L., Corell, R.W., Fabry, V.J., Hansen, J., Walker, B., Liverman, D., Richardson, K., Crutzen, P.J. and Foley, J.A. (2009a), "Planetary Boundaries: Exploring the Safe Operating Space for Humanity", Ecology and Society, 14(2): 32. Online version (accessed 5 July 2012):

http://www.ecologyandsociety.org/vol14/iss2/art32/. (Cited on pages 5 and 7.)

Rockström, J., Steffen, W., Noone, K., Persson, Å., Chapin III, F.S., Lambin, E.F., Lenton, T.M., Scheffer, M., Folke, C., Schellnhuber, H.J., Nykvist, B., de Wit, C.A., Hughes, T., van der Leeuw, S., Rodhe, H., Sörlin, S., Snyder, P.K., Costanza, R., Svedin, U., Falkenmark, M., Karlberg, L., Corell, R.W., Fabry, V.J., Hansen, J., Walker, B., Liverman, D., Richardson, K., Crutzen, P.J. and Foley, J.A. (2009b), "A safe operating space for humanity", Nature, 461: 472-475, [DOI]. (Cited on pages 7 and 9.)

Ruddiman, W.F. (2003), "The Anthropogenic Greenhouse Era Began Thousands of Years Ago", Climatic Change, 61(3): 261-293, [DOI]. (Cited on pages 7 and 20.)

Ruddiman, W.F. and Ellis, E.C. (2009), "Effect of per-capita land use changes on Holocene forest clearance and $\mathrm{CO}_{2}$ emissions", Quaternary Science Reviews, 28(27-28): 3011-3015, [DOI]. (Cited on page 10.) 
Sachs, I. (2011), "Entering the anthropocene: 'Geonauts' or sorcerer's apprentices?", Social Science Information, 50(3-4): 462-471, [DOI]. (Cited on page 7.)

Sassen, S. (2009), "Bridging the Ecologies of Cities and of Nature", in Qu, L., Yang, C., Hui, X. and Sepúlveda, D., eds., The New Urban Question - Urbanism Beyond Neo-Liberalism, The 4th Conference of the International Forum on Urbanism (IFoU), Amsterdam/Delft, November 26-28, 2009, pp. 45-52, Delft (IFoU). URL (accessed 3 July 2012): http://newurbanquestion.ifou.org/proceedings/. (Cited on page 13.)

Schaldach, R. and Priess, J.A. (2008), "Integrated Models of the Land System: A Review of Modelling Approaches on the Regional to Global Scale", Living Reviews in Landscape Research, 2(1). URL (accessed 12 March 2011):

http://www.livingreviews.org/lrlr-2008-1. (Cited on pages 14 and 20.)

Schlütz, F. and Lehmkuhl, F. (2009), "Holocene climatic change and the nomadic Anthropocene in Eastern Tibet: palynological and geomorphological results from the Nianbaoyeze Mountains", Quaternary Science Reviews, 28(15-16): 1449-1471, [DOI]. (Cited on pages 7 and 20.)

Scott, A. (2011), "Beyond the conventional: Meeting the challenges of landscape governance within the European Landscape Convention?", Journal of Environmental Management, 92(10): 2754-2762, [DOI]. (Cited on page 12.)

Scott, A. and Shannon, P. (2007), "Local landscape designations in Scotland: Opportunity or barrier to effective landscape management?", Landscape and Urban Planning, 81(3): 257-269, [DOI]. (Cited on page 12.)

SEDAC/CIESIN (2005), "Gridded Population of the World, Version 3 (GPWv3) and Global Rural-Urban Mapping Project, Version 1 (GRUMPv1)", project homepage, Columbia University. URL (accessed 12 March 2011):

http://sedac.ciesin.columbia.edu/gpw/. (Cited on page 13.)

Seto, K.C. and Satterthwaite, D. (2010), "Interactions between urbanization and global environmental change", Current Opinion in Environmental Sustainability, 2(3): 127-128, [DOI]. (Cited on page 13.)

Slaughter, R.A. (2010), "Welcome to the anthropocene", Futures, 44(2): 119-126, [DOI]. (Cited on page 6.)

Steffen, W., Grinevald, J., Crutzen, P.J. and McNeill, J. (2011), "The Anthropocene: conceptual and historical perspectives", Philosophical Transactions of the Royal Society of London, Series A, 369(1938): 842-867, [DOI]. (Cited on pages 6 and 14.)

Stone Jr, B. (2009), "Land Use as Climate Change Mitigation", Environmental Science E Technology, 43(24): 9052-9056, [DOI]. (Cited on page 13.)

Syvitski, J.P.M. (2012), "Anthropocene: An Epoch of Our Making", Global Change, 78: 12-15. Online version (accessed 5 July 2012):

http://www.igbp.net/news/features/features/anthropoceneanepochofourmaking.html. (Cited on page 7.)

Syvitski, J.P.M. and Kettner, A. (2011), "Sediment flux and the Anthropocene", Philosophical Transactions of the Royal Society of London, Series A, 369(1938): 957-975, [DOI]. (Cited on page 10.)

The Economist (2010), "The data deluge: Businesses, governments and society are only starting to tap its vast potential", online resource, The Economist. URL (accessed 5 July 2012): http://www.economist.com/node/15579717. (Cited on page 5.)

The Economist (2011), "Welcome to the Anthropocene: Humans have changed the way the world works. Now they have to change the way they think about it, too", online resource, The Economist. URL (accessed 5 July 2012):

http://www.economist.com/node/18744401. (Cited on page 14.) 
Tian, Y., Jim, C.Y., Tao, Y. and Shi, T. (2011), "Landscape ecological assessment of green space fragmentation in Hong Kong", Urban Forestry $\&$ Urban Greening, 10(2): 79-86, [DOI]. (Cited on page 10.)

Tickell, C. (2011), "Societal responses to the Anthropocene", Philosophical Transactions of the Royal Society of London, Series A, 369(1938): 926-932, [DOI]. (Cited on page 14.)

Tolle, K.M., Tansley, D. and Hey, A.J.G. (2011), "The Fourth Paradigm: Data-Intensive Scientific Discovery (Point of View)", Proceedings of the IEEE, 99(8): 1334-1337, [DOI]. (Cited on page 16.)

Tress, G., Tress, B., Fry, G. and Antrop, M. (2006), "Trends in landscape research and landscape planning: implications for PhD students", in Tress, B., Tress, G., Fry, G. and Opdam, P., eds., From Landscape Research to Landscape Planning: Aspects of Integration, Education and Application, Proceedings of the Frontis Workshop, Wageningen, The Netherlands 1-6 June 2004, Wageningen UR Frontis Series, 12, pp. 1-10, Dordrecht (Springer). [Google Books], Online version (accessed 3 July 2012):

http://library.wur.nl/ojs/index.php/frontis/article/view/1094. (Cited on page 5.)

Troll, C. (1971), "Landscape Ecology (Geoecology) and Biogeocenology-A Terminology Study", Geoforum, 2(8): 43-46, [DOI]. (Cited on page 12.)

Turney, C.S.M. and Brown, H. (2007), "Catastrophic early Holocene sea level rise, human migration and the Neolithic transition in Europe", Quaternary Science Reviews, 26(17-18): 2036-2041, [DOI]. (Cited on page 10.)

UN-Habitat (2003), "The Challenge of Slums: Global Report on Human Settlements 2003", Global Report on Human Settlements, London; Sterling, VA (Earthscan). Online version (accessed 5 July 2012): http://www . unhabitat.org/content. asp?typeid=19\&catid=555\&cid=5373. (Cited on page 13.)

Uuemaa, E., Antrop, M., Roosaare, J., Marja, R. and Mander, Ü. (2009), "Landscape Metrics and Indices: An Overview of Their Use in Landscape Research", Living Reviews in Landscape Research, 3(1). URL (accessed 3 July 2012):

http://www.livingreviews.org/lrlr-2009-1. (Cited on pages 5, 14, and 20.)

Walker, M., Johnsen, S., Rasmussen, S.O., Popp, T., Steffensen, J.-P., Gibbard, P., Hoek, W., Lowe, J., Andrews, J., Björck, S., Cwynar, L.C., Hughen, K., Kershaw, P., Kromer, B., Litt, T., Lowe, D.J., Nakagawa, T., Newnham, R. and Schwander, J. (2009), "Formal definition and dating of the GSSP (Global Stratotype Section and Point) for the base of the Holocene using the Greenland NGRIP ice core, and selected auxiliary records", Journal of Quaternary Science, 24(1): 3-17, [DOI]. (Cited on page 7.)

Wilcox, B.P., Sorice, M.G. and Young, M.H. (2011), "Dryland Ecohydrology in the Anthropocene: Taking Stock of Human-Ecological Interactions", Geography Compass, 5(3): 112-127, [DOI]. (Cited on page 13.)

World Bank (2009), "World Development Report 2009: Reshaping Economic Geography", Washington DC (World Bank), [DOI]. (Cited on page 13.)

Yuen, B. and Kong, L. (2009), "Climate Change and Urban Planning in Southeast Asia", S.A.P.I.EN.S, 2(3): 881. URL (accessed 16 December 2010): http://sapiens.revues.org/881. (Cited on page 13.)

Zalasiewicz, J. (2011), "The Dawn of the Anthropocene Era: 'We are the Top Predator on Earth"', online resource, Spiegel Online International. URL (accessed 5 July 2012): http://www.spiegel.de/international/world/a-765362.html. (Cited on page 14.)

Zalasiewicz, J., Williams, M., Smith, A., Barry, T.L., Coe, A.L., Bown, P.R., Brenchley, P., Cantrill, D., Gale, A., Gibbard, P., Gregory, F.J., Hounslow, M.W., Kerr, A.C., Pearson, P., Knox, R., Powell, J., Waters, C., Marshall, J., Oates, M., Rawson, P. and Stone, P. (2008), "Are we now living in the Anthropocene?", GSA Today, 18(2): 4-8, [DOI]. (Cited on pages 6 and 20.) 
Zalasiewicz, J., Williams, M., Steffen, W. and Crutzen, P.J. (2010), "The New World of the Anthropocene", Environmental Science \&3 Technology, 44(7): 2228-2231, [DOI]. (Cited on page 7.)

Zalasiewicz, J., Williams, M., Haywood, A. and Ellis, M. (2011), "The Anthropocene: a new epoch of geological time?", Philosophical Transactions of the Royal Society of London, Series A, 369(1938): 835841, [DOI]. (Cited on pages 5, 10, 14, and 20.)

Zhu, J. (2002), "Industrial globalisation and its impact on Singapore's industrial landscape", Habitat International, 26(2): 177-190, [DOI]. (Cited on page 13.)

Zonneveld, I.S. (1989), "The land unit - A fundamental concept in landscape ecology, and its applications", Landscape Ecology, 3(2): 67-86, [DOI]. (Cited on page 12.)

Zube, E.H., Sell, J.L. and Taylor, J.G. (1982), "Landscape Perception: Research, Application and Theory", Landscape Planning, 9(1): 1-33. (Cited on page 10.) 